\title{
Energy Balance, Physical Activity, and Thermogenic Effect of Feeding in Premature Infants
}

\author{
DANIEL FREYMOND, YVES SCHUTZ, JACQUES DECOMBAZ, JEAN-L. MICHELI, AND \\ ERIC JÉQUIER \\ Departments of Pediatrics and Clinical Physiology, University Medical School, Lausanne, Switzerland
}

\begin{abstract}
In order to assess the contribution of the thermogenic effect of feeding and muscular activity to total energy expenditure, nine premature infants were studied for 2 consecutive days during which time repeated measurements of energy expenditure by indirect calorimetry were performed throughout the day, combined with a visual activity score based on body movement. The infants were growing at $16.6 \pm 4.0 \mathrm{~g} / \mathrm{kg} /$ day (mean $\pm \mathrm{SD}$ ) and received $110 \pm 8 \mathrm{kcal} / \mathrm{kg} /$ day metabolizable energy (milk formula) and $522 \pm 40 \mathrm{mg} \mathrm{N} / \mathrm{kg} / \mathrm{day}$. Their total energy expenditure was $68 \pm 4 \mathrm{kcal} / \mathrm{kg} /$ day indicating that $41 \pm 7 \mathrm{kcal} / \mathrm{kg} /$ day was retained for growth. Based on the combination of energy $+N$ balances it was estimated that $80 \%$ of the weight gain was fat-free tissue and $20 \%$ was fat tissue. The rate of energy expenditure measured minute-by-minute was significantly and linearly correlated with the activity score in both the premeal $(r=0.75 ; p<0.001)$ and the postmeal periods $(r=0.74 ; p<0.001)$ with no difference in the regression slope, but with a significant difference in intercept. In preset feeding schedules the latter allowed an estimation of the thermogenic effect without the confounding effect of activity. This was found to be $3.1 \pm 1.8 \%$ when expressed as a percentage of metabolizable energy intake. However when the "classical" approach was used as a comparison (integretation of extra energy expenditure induced by the meal), the thermogenic effect was found to be greater, i.e. $9.5 \pm 3.8 \%$ of the meal's metabolizable energy, due to the superimposed effect of physical activity in the postprandial state. The study suggests that the intradaily variation in energy expenditure in premature infants nursed according to present day techniques is almost equally due to the thermogenic effect of feeding (3.2 $\mathrm{kcal} / \mathrm{kg} /$ day), and to variations in muscular activity (3.6 $\mathrm{kcal} / \mathrm{kg} / \mathrm{day}$ ) both representing a small fraction of the total energy expenditure in premature infants (i.e. 4.7 and $5.3 \%$, respectively). (Pediatr Res 20: 638-645, 1986)
\end{abstract}

\section{Abbreviations}

CHO, carbohydrate

REM, rapid eye movement

R.Q., respiratory quotient

Since the development of open system indirect calorimeters (1-6) allowing measurements under ordinary conditions of nurs-

Received August 7, 1985; accepted February 25, 1986.

Jean-L.Micheli, M.D., Neonatal Unit, Department of Pediatrics. C.H.U.V., CHJean-L.Micheli, M.D., Neona
1011 Lausanne, Switzerland.

This work was supported by a research grant from Nestlé, Vevey Switzerland. ing and feeding, the study of energy metabolism in preterm infants has progressed at a rapid pace. However, measurements of energy expenditure in premature babies have been generally of short duration $(5,7-9)$, i.e. approximately $1-3 \mathrm{~h}$. Therefore the extent to which these limited periods of measurement can be extrapolated to $24 \mathrm{~h}$ is still uncertain. When energy expenditure of preterm infants is continuously monitored over $24 \mathrm{~h} \mathrm{(6)}$, the variability of measurements generally observed is mainly due to two factors: variations in physical activity (i.e. whole body movements, crying), and the thermogenic response to feeding.

Although several methods have been developed to score changes in spontaneous physical activity of infants $(7,9-16)$, it is not known to what extent these scores are related to the rate of energy expenditure. Because the thermogenic response itself can be influenced by several factors such as duration of measurement, feeding frequency, size and type of test meal, the published measurements give variable results $(9,12,17-20)$. The aims of the present study was to measure the energy metabolism of premature babies of less than 34 gestational wk, to assess the magnitude of intradaily variations in energy expenditure and to partition the latter between muscular activity and thermogenic response to feeding.

\section{PATIENTS AND METHOD}

Infants. Nine premature babies were studied for 2 consecutive days. All were all appropriate for gestational age (mean $33 \pm 1.2$ wk; $1740 \pm 180 \mathrm{~g}$ birth weight; $43 \pm 1.5 \mathrm{~cm}$ length; $29.7 \pm 0.9$ $\mathrm{cm}$ head circumference, age at study $21 \pm 5$ days). None had major medical problems, none had neurologic problems, and ultrasound evaluations showed that none had undergone major intraventricular hemorrage or significant periventricular leucomalacia.

The purpose and the procedures of the study were carefully explained to the parents and their agreement was obtained. Most parents were at the bedside while the measurements were done. The investigation has been approved by the Ethical Committee of the Medical Faculty, University of Lausanne.

Diet. All infants were fed through a nasogastric tube (Argyle). The volume of every meal was precisely measured with a $10-\mathrm{ml}$ syringe. Seven infants had their diet distributed in eight meals/ day, the remaining two in 10 and 12 meals/day, respectively. Their supply in calories, protein (expressed as N), lipid, and CHO is shown in Table 1. They were all fed a formula adapted for preterm infants (Alprem, Nestlé). Three infants received part of their daily feeding as their own mother's milk. The diet administrated during the studies had been initiated at least 2 days before the study onset. An aliquot of milk formula and breast milk was immediately sampled and frozen. According to the volume of diet actually ingested by the infant, a pool of formula 
Table 1. Balances of energy and nutrients

\begin{tabular}{|c|c|c|c|c|c|c|c|c|}
\hline Infant & $\begin{array}{c}\text { Gross } \\
\text { energy intake }\end{array}$ & $\begin{array}{c}\text { Metabolizable energy } \\
\text { intake } \\
(\mathrm{kcal} / \mathrm{kg} / \text { day })\end{array}$ & $\begin{array}{c}\text { Energy } \\
\text { expenditure }\end{array}$ & $\begin{array}{c}\text { Energy } \\
\text { gain }\end{array}$ & $\begin{array}{c}\text { Gross } \\
\mathrm{N}^{*} \text { intake }\end{array}$ & $\begin{array}{l}\mathrm{N} \\
\text { digested } \\
(\mathrm{mg} / \mathrm{kg} / \text { day })\end{array}$ & $\begin{array}{l}\text { Urinary } \\
\mathrm{N} \\
\end{array}$ & $\begin{array}{l}\mathrm{N} \\
\text { gain }\end{array}$ \\
\hline PG & 128.6 & 106.4 & 64.4 & 42.0 & 541 & 429 & 89 & 340 \\
\hline $\mathrm{AL}$ & 124.7 & 115.5 & 71.2 & 44.3 & 542 & 506 & 254 & 252 \\
\hline SB & 117.3 & 107.6 & 66.0 & 41.6 & 492 & 428 & 141 & 287 \\
\hline ED & 120.0 & 115.0 & 73.3 & 41.7 & 522 & 505 & 160 & 345 \\
\hline DP & 139.7 & 126.9 & 74.0 & 52.9 & 608 & 575 & 232 & 343 \\
\hline $\mathrm{SF}$ & 129.6 & 104.2 & 70.0 & 34.2 & 500 & 417 & 174 & 243 \\
\hline MS & 121.0 & 107.7 & 66.3 & 41.4 & 527 & 461 & 120 & 341 \\
\hline $\mathbf{L J}$ & 114.4 & $105.6 \dagger$ & 60.6 & 45.5 & 498 & $470 \dagger$ & 95 & 375 \\
\hline JK & 107.7 & 99.0 & 69.9 & 29.1 & 469 & 463 & 94 & 369 \\
\hline Mean & 122.6 & 109.8 & 68.4 & 41.4 & 522 & 473 & 151 & 322 \\
\hline$\pm \mathrm{SD}$ & 9.4 & 8.2 & 4.4 & 6.7 & 40 & 50 & 60 & 49 \\
\hline Infant & $\begin{array}{c}\text { Gross } \\
\text { lipid intake }\end{array}$ & $\begin{array}{l}\text { Lipid } \\
\text { digested } \\
\quad(\mathrm{g} / \mathrm{kg} / \text { day }) \\
\end{array}$ & $\begin{array}{l}\text { Lipid } \\
\text { oxid. } \neq\end{array}$ & $\begin{array}{l}\text { Lipid } \\
\text { gain } \$\end{array}$ & $\begin{array}{c}\text { Gross } \\
\text { CHO intake }\end{array}$ & $\begin{array}{l}\mathrm{CHO} \\
\text { digested } \\
(\mathrm{g} / \mathrm{kg} / \text { day })\end{array}$ & $\begin{array}{c}\text { CHO } \\
\text { oxid. } \ddagger\end{array}$ & $\begin{array}{l}\mathrm{CHO} \\
\text { gain } \ddagger\end{array}$ \\
\hline PG & 5.7 & 3.9 & 0.6 & 3.3 & 14.9 & 14.7 & 13.3 & +1.4 \\
\hline $\mathrm{AL}$ & 5.9 & 5.1 & 0.2 & 4.9 & 13.9 & 13.9 & 14.7 & -0.8 \\
\hline $\mathrm{SB}$ & 5.8 & 5.1 & 0.9 & 4.2 & 12.5 & 12.5 & 12.8 & -0.3 \\
\hline $\mathrm{ED}$ & 5.7 & 5.4 & 1.1 & 4.3 & 13.3 & 13.2 & 13.9 & -0.7 \\
\hline DP & 6.6 & 5.4 & -0.2 & 5.7 & 15.3 & 15.3 & 16.6 & -1.3 \\
\hline $\mathrm{SF}$ & 5.5 & 3.9 & 0.3 & 3.6 & 16.0 & 14.2 & 14.9 & -0.7 \\
\hline MS & 5.7 & 4.5 & 0.5 & 4.0 & 13.4 & 13.4 & 13.9 & -0.5 \\
\hline $\mathrm{LJ}$ & 5.4 & $4.6 \dagger$ & 0.7 & 3.9 & 12.7 & $12.7 \dagger$ & 12.2 & +0.5 \\
\hline JK & 5.1 & 4.4 & 1.8 & 2.5 & 12.0 & 11.6 & 12.1 & -0.5 \\
\hline Mean & 5.7 & 4.7 & 0.7 & 3.9 & 13.8 & 13.5 & 13.8 & -0.3 \\
\hline$\pm \mathrm{SD}$ & 0.4 & 0.6 & 0.6 & 1.0 & 1.4 & 1.2 & 1.4 & 0.8 \\
\hline
\end{tabular}

$* \mathrm{~N} \times 6.38=$ protein.

$\dagger$ Assuming: energy digest. $=92.8 \% ; \mathrm{N}$ digest. $=94.2 \% ;$ lipid digest. $=85.7 \%$ assumed values $=$ mean of corresponding values in our completely formula fed infants (PG, AL, ED, MS, JK).

$\$$ Assessed by the R.Q. method (see text).

(and of breast milk) constituted the diet composition of the 2 days together.

Gross intake, net intake (apparent digestible energy), apparent digestibility, and metabolizable energy. Gross energy was determined by bomb calorimetry (Parr Instrument, Chicago, IL); gross protein intake via total nitrogen (Kjeldahl) and gross lipid intake was derived from the measurement of esterified glycerol (Boehringer, Mannheim, Germany). The energy provided by gross $\mathrm{CHO}$ intake was obtained from equations 1 and 2 (Appendix). The gross supply of $\mathrm{CHO}$ (in $\mathrm{g} / \mathrm{kg} /$ day) was computed using the energy equivalent of lactose, $3.95 \mathrm{kcal} / \mathrm{g}$ for mothers' milk, and an energy equivalent of $3.86 \mathrm{kcal} / \mathrm{g}$ for formula (the milk formula contained one-third of its $\mathrm{CHO}$ as glucose and two-thirds as lactose). Apparent digestible energy was calculated by subtracting the energy content of feces (bomb calorimetry) from the gross energy intake (equation 3).

The stools were collected separately from urine during an average period of $42 \pm 9 \mathrm{~h}$, and analyzed according to a previously described method (21). Equations 4-8 define the apparent digestibility of $\mathrm{N}$, lipid, $\mathrm{CHO}$, and the metabolizable energy. Urine was continuously collected during an average period of 45 $\pm 4 \mathrm{~h}$ an adhesive plastic bag connected via a plastic tube to a $50-\mathrm{ml}$ glass cylinder. It contained $0.1 \mathrm{ml} \mathrm{HCl} 6 \mathrm{~N}$ and was surrounded by melting ice. The cylinders were changed before each meal and were kept at $0^{\circ} \mathrm{C}$ until analysis. The 24 -h volume was pooled. Urea (urease method), creatinine (Jaffé reaction), and total $\mathrm{N}$ were measured in the 24-h urine pools of the study. Glucosuria was absent in all infants as assessed by clinitest sticks (Boehringer).

Energy expenditure and activity scores. A previously described, open circuit indirect calorimeter was used to measure energy expenditure (5). Briefly the calorimeter consists of an airtight perspex box, containing the whole infant, placed inside the incubator. The infant's $\mathrm{VO}_{2}$ and $\mathrm{VCO}_{2}$ is obtained by the difference of $\mathrm{O}_{2}$ and $\mathrm{CO}_{2}$ fractions measured at the inlet and the outlet. From these data and total urinary $\mathrm{N}$, energy expenditure is computed on the basis of oxygen volumes required to oxidize $\mathrm{CHO}$, lipid, and protein (equations 9-12). During calorimetry the activity state of each infant was monitored minute by minute using the scale developed by Brück et al. (10) and simultaneously by a simplified activity scale (Table 2 ). The assessments were performed by the same investigator. Since the rate of activity may change within a single minute, the highest score of activity observed over the minute considered was recorded. the assessment of activity was synchronized to the measurement of energy expenditure by moving the calorimetric values back by $2 \mathrm{~min}$. This time lag was assessed for our calorimeter (5) and includes a $50 \%$ exponential mixing time.

Energy retention, assessment of growth, and composition of weight gain. The retained energy was calculated from the difference between metabolizable energy and energy expenditure (equation 13). Body weight was measured every day to the nearest $10 \mathrm{~g}$. The rate of weight gain was calculated over the week which bracketed the study period. In order to minimize the influence of day to day variations the gain was calculated using the least square regression line of daily weight versus time. However, the energy results were referred to the actual infant's body weight on the day of the measurement. The composition of the infant's weight gain was estimated by two different methods. The first method was based on the measurements of the energy gain in 
Table 2. Activity scales

Brück's activity scale $(10)$
+5
+4
+3
+2
+1
0
-1
-2
-3
-4

Simplified activity scale 0

\author{
Crying \\ Eyes open \\ Eyes open \\ Eyes open \\ Eyes open \\ Eyes opening and closing \\ Eyes closed \\ Eyes closed \\ Eyes closed \\ Eyes closed
}

Total body movement

Arm and/or leg movement

Facial movement

No movement

No movement

Total body movement

Arm and/or leg movement

Facial movement

No movement
No body, arm, or leg
movement; facial
Eyes closed or open
movements present or not
Arm or leg movement
Total body movement
Eyes closed or open
Eyes closed or open

conjunction with the Nitrogen balance (equations 13-16). The second method (R.Q. method) was based on the nutrient balance obtained by subtracting the nutrients oxidized from the nutrient intake (equations 17 and 18). The fat free mass was calculated by difference between the weight gain and the lipid gain (equation 19). The weight gain not due to protein, fat, and $\mathrm{CHO}$ retentions was assumed to represent noncaloric compounds such as water, bone minerals, and electrolytes.

Analysis of data. Since discontinuous calorimetric measurements were performed at various times throughout the study (Fig. 1), three distinct periods were defined: 1) the premeal period consisting of $30 \mathrm{~min}$ of continuous measurement immediately before the meal; 2) the postmeal period measured over $180 \mathrm{~min}$ after the meal, and 3) the peak thermogenic response to feeding measured during $30 \mathrm{~min}$ (30-60 min postmeal). The energy expenditure during each of these periods was calculated by simple arithmetic average. The so-called overall daily energy expenditure was obtained by a weightened average procedure taking into account the number of meals fed per day, i.e. by calculating the contribution of each period to the total energy expenditure. In order to estimate the energetic cost of physical activity, the minute by minute energy expenditure was related to the corresponding physical activity estimated simultaneously by Brück's scale (10) and the simplified activity scale (see Table 1), both in the premeal and postmeal periods. A similar approach has been used previously with adults (22).

The thermogenic response to feeding was estimated by two methods: the "classic" one obtained by comparison between premeal and postmeal measurements (equations 20 and 21). The premeal baseline was the energy expenditure measured over a 3to 5-min period of inactivity (zero activity on the simplified scale) during the $30-\mathrm{min}$ premeal period. The postmeal excess of energy expenditure above the baseline was measured over a 180min period. This value was taken as the thermogenic effect of feeding provided the infant keeps quiet during the postmeal calorimetry. This shortcoming can be obviated by the second or "regression" method. Two regression lines of energy expenditure versus activity are drawn: the first corresponds to the minute by minute synchronized measurements of energy expenditure and activity (0-3 scale) during the premeal period; the second corresponds to the same measurements, but done during the postmeal period. The difference between the premeal and the postmeal regression line gave an estimate of the thermogenic effect of food intake without the confounding effect of physical activity.

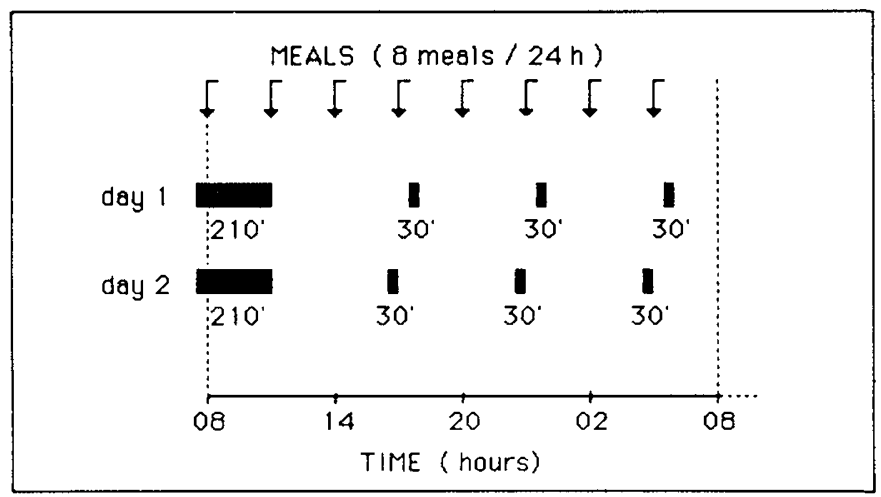

Fig. 1. Experimental design. Each day, 4 to $5 \mathrm{~h}$ of discontinued calorimetric measurements were performed (black bars): one "long" measurement of $210 \mathrm{~min}$ aimed to obtain the complete thermogenic response to a meal and three "short" measurements. On day 1 , the "short" runs of $30 \mathrm{~min}$ were performed $30-60 \mathrm{~min}$ after the beginning of the meal, aimed to scan the peak thermogenic effect. The whole procedure was repeated on day 2 , except that the "short" runs had a different timing in order to investigate the premeal period $(30-0 \mathrm{~min}$ before meal).

\section{RESULTS}

Energy and nutrient balances. Table 1 shows the individual values for energy, protein lipid, and $\mathrm{CHO}$. The energy digestibility was $90.1 \pm 5.4 \%$ (mean $\pm \mathrm{SD}$ ). The nitrogen, lipid, and CHO digestibilities averaged respectively $90.1 \pm 6.8,81.9 \pm 9.1$, and $97.9 \pm 3.9 \%$

There was a significant correlation between energy digestibility and lipid digestibility $(r=0.963, n=8, p<0.001)$. The metabolizable energy intake was $109.8 \pm 8.2 \mathrm{kcal} / \mathrm{kg} / \mathrm{day}$, a value $10 \%$ lower than the gross energy intake. The overall daily energy expenditure averaged $68.4 \pm 4.4 \mathrm{kcal} / \mathrm{kg} /$ day. The $\mathrm{N}$ gain was $+0.322 \pm 0.049 \mathrm{~g} \mathrm{~N} / \mathrm{kg} /$ day or $2.0 \pm 0.3 \mathrm{~g}$ retained protein/ $\mathrm{kg} /$ day. The lipid balance was largely positive $(3.9 \pm 1.0 \mathrm{~g} / \mathrm{kg} /$ day), whereas the $\mathrm{CHO}$ gain was close to zero $(-0.3 \pm 0.8 \mathrm{~g} / \mathrm{kg} /$ day).

Weight gain and composition of weight gain (Table 3). The mean rate of weight gain of the studied infants was $16.6 \pm 4$ $\mathrm{g} / \mathrm{kg} /$ day, representing an energy gain $41.4 \pm 6.7 \mathrm{kcal} / \mathrm{kg} /$ day, i.e. $38 \%$ of metabolizable intake, $87 \%$ of this energy was due to fat, the remaining part to protein retention. Estimates of the 
composition of weight gain by either described method gave similar results (compare Tables 1 and 3): $\mathrm{CHO}$ retention was negligible; $80 \%$ of weight gain was fat free mass whose average protein content was $16 \pm 4 \%$ and $20 \%$ of weight gain was fat.

Energy expenditure and physical activity. Table 4 shows the individual values for the rate of energy expenditure, the degree of physical activity using Brück's scale and the simplified activity scale, and the respiratory quotient. Comparison of morning versus afternoon measurements showed no significant daytime variation for energy expenditure or activity. Furthermore no difference was found between days 1 and 2 . There was a curvilinear relationship (3rd degree regression curve, $r=0.752$ ) between Brück's activity score and energy expenditure (Fig. 2).

Figure 3 upper diagram shows the individual values of energy expenditure at each level of the simplified activity scale. Figure 3 lower diagram shows the linear relationship between energy expenditure and activity. The two regression lines correspond to the premeal period and to the peak thermogenic period following the meal. The mean activity in the premeal period was significantly greater than after the meal $(0.93$ respectively 0.66 units

Table 3. Composition of wt gain estimated from energy and nitrogen balance

\begin{tabular}{|c|c|c|c|c|c|c|c|c|}
\hline Infant & $\begin{array}{l}\text { Wt } \\
\text { gain } \\
(\mathrm{g})\end{array}$ & $\begin{array}{l}\text { Protein } \\
\text { gain } \\
\text { day) }\end{array}$ & $\begin{array}{c}\text { Energy } \\
\text { stored in protein* } \\
(\mathrm{kcal} / 1)\end{array}$ & $\begin{array}{l}\text { Energy } \\
\text { stored in lipid* } \\
\text { lay) }\end{array}$ & $\begin{array}{l}\text { Lipid gain* } \\
\qquad(\mathrm{g} / \mathrm{kg}\end{array}$ & $\begin{array}{l}\text { Fat-free } \\
\text { mass } \\
\end{array}$ & $\begin{array}{c}\text { Fat-free } \\
\text { mass }\end{array}$ & $\begin{array}{l}\begin{array}{c}\text { Protein } \\
\text { fat-free mass } \\
(\%)\end{array} \\
\end{array}$ \\
\hline PG & 24.8 & 2.1 & 11.9 & 30.1 & 3.2 & 21.6 & 87 & 10 \\
\hline $\mathrm{AL}$ & 13.9 & 1.6 & 8.9 & 35.5 & 3.8 & 10.1 & 73 & 16 \\
\hline SB & 14.3 & 1.8 & 10.0 & 31.6 & 3.4 & 10.9 & 76 & 16 \\
\hline ED & 18.2 & 2.2 & 12.1 & 29.6 & 3.3 & 14.9 & 82 & 14 \\
\hline DP & 16.6 & 2.1 & 12.0 & 40.9 & 4.4 & 12.2 & 74 & 18 \\
\hline $\mathrm{SF}$ & 13.1 & 1.5 & 8.5 & 25.7 & 2.8 & 10.3 & 79 & 15 \\
\hline MS & 11.5 & 2.1 & 11.9 & 29.5 & 3.2 & 8.3 & 72 & 26 \\
\hline $\mathrm{LJ}$ & 18.6 & 2.3 & 13.1 & 31.9 & 3.4 & 15.2 & 82 & 15 \\
\hline JK & 18.2 & 2.3 & 12.9 & 16.2 & 1.7 & 16.5 & 91 & 14 \\
\hline Mean & 16.6 & 2.0 & 11.3 & 30.1 & 3.2 & 13.3 & 84 & 16 \\
\hline$\pm \mathrm{SD}$ & 4.0 & 0.3 & 1.7 & 6.7 & 0.7 & 4.1 & 6 & 4 \\
\hline
\end{tabular}

* Energy stored in protein $=$ protein gain $\times 5.6(\mathrm{kcal} / \mathrm{kg} /$ day $)$ energy stored in lipid $=$ energy gain-energy stored in protein lipid gain $=$ energy stored in lipid/9.3 (kcal/g).

Table 4. Energy expenditure, physical activity, and R.Q.

\begin{tabular}{|c|c|c|c|c|c|c|c|c|}
\hline \multicolumn{5}{|c|}{$30-60 \mathrm{~min}$ before meal } & \multicolumn{4}{|c|}{$30-60 \mathrm{~min}$ after meal } \\
\hline \multirow[b]{2}{*}{ Infant } & \multirow[b]{2}{*}{$\begin{array}{c}\text { Energy expenditure } \\
(\mathrm{kcal} / \mathrm{kg} / \text { day })\end{array}$} & \multicolumn{2}{|c|}{ Activity } & \multirow[b]{2}{*}{ R.Q. } & \multirow[b]{2}{*}{$\begin{array}{c}\text { Energy expenditure } \\
(\mathrm{kcal} / \mathrm{kg} / \text { day })\end{array}$} & \multicolumn{2}{|c|}{ Activity } & \multirow[b]{2}{*}{ R.Q. } \\
\hline & & $\begin{array}{c}0-3 \\
\text { scale }\end{array}$ & $\begin{array}{c}\text { Brück's } \\
\text { scale }\end{array}$ & & & $\begin{array}{c}0-3 \\
\text { scale }\end{array}$ & $\begin{array}{l}\text { Brück's } \\
\text { scale }\end{array}$ & \\
\hline $\mathrm{PG}$ & 65.1 & 0.93 & -1.8 & 0.96 & 67.9 & 0.73 & -2.6 & 0.97 \\
\hline $\mathrm{AL}$ & 71.5 & 1.30 & +1.0 & 0.94 & 69.4 & 0.43 & -2.0 & 1.02 \\
\hline SB & 65.4 & 0.90 & -0.9 & 0.95 & 67.2 & 0.55 & -1.6 & 0.97 \\
\hline $\mathrm{ED}$ & 73.7 & 0.93 & -1.1 & 0.94 & 69.7 & 0.75 & -2.2 & 0.94 \\
\hline DP & 73.3 & 1.06 & -0.2 & 1.04 & 74.0 & 0.78 & -1.6 & 0.99 \\
\hline SF & 70.2 & 0.86 & -0.8 & 0.97 & 70.8 & 0.60 & -2.0 & 0.99 \\
\hline $\mathrm{MS}^{*}$ & 65.2 & 0.67 & -1.1 & 0.97 & 69.1 & 0.66 & -2.3 & 0.96 \\
\hline $\mathrm{LJ}^{* *}$ & 57.8 & 0.70 & -1.5 & 0.96 & 63.4 & 0.60 & -1.8 & 0.99 \\
\hline $\mathrm{JK}$ & 67.0 & 0.99 & -1.0 & 0.95 & 72.2 & 0.87 & -1.3 & 0.94 \\
\hline Mean & 66.6 & 0.93 & -0.82 & 0.96 & 69.3 & 0.66 & -1.9 & 0.97 \\
\hline \multirow{2}{*}{$\pm \mathrm{SD}$} & 6.2 & 0.19 & 0.82 & 0.03 & 3.0 & 0.13 & 0.4 & 0.03 \\
\hline & \multicolumn{3}{|c|}{ Average over $24 \mathrm{~h}$} & & & & & \\
\hline PG & 64.4 & 0.72 & -2.5 & 0.96 & & & & \\
\hline $\mathrm{AL}$ & 71.2 & 0.92 & -0.4 & 0.97 & & & & \\
\hline SB & 66.0 & 0.82 & -1.4 & 0.95 & & & & \\
\hline ED & 73.3 & 0.87 & -1.6 & 0.94 & & & & \\
\hline DP & 74.0 & 0.91 & -1.1 & 0.99 & & & & \\
\hline $\mathrm{SF}$ & 70.0 & 0.75 & -1.5 & 0.94 & & & & \\
\hline $\mathrm{MS}^{*}$ & 66.3 & 0.66 & -2.0 & 0.97 & & & & \\
\hline $\mathrm{LJ} \dagger$ & 60.6 & 0.67 & -1.6 & 0.96 & & & & \\
\hline JK & 69.9 & 0.92 & -1.5 & 0.92 & & & & \\
\hline Mean & 68.4 & 0.80 & -1.5 & 0.96 & & & & \\
\hline$\pm \mathrm{SD}$ & 4.4 & 0.11 & 0.6 & 0.02 & & & & \\
\hline
\end{tabular}

* Twelve meals/day.

$\dagger$ Ten meals/day. 


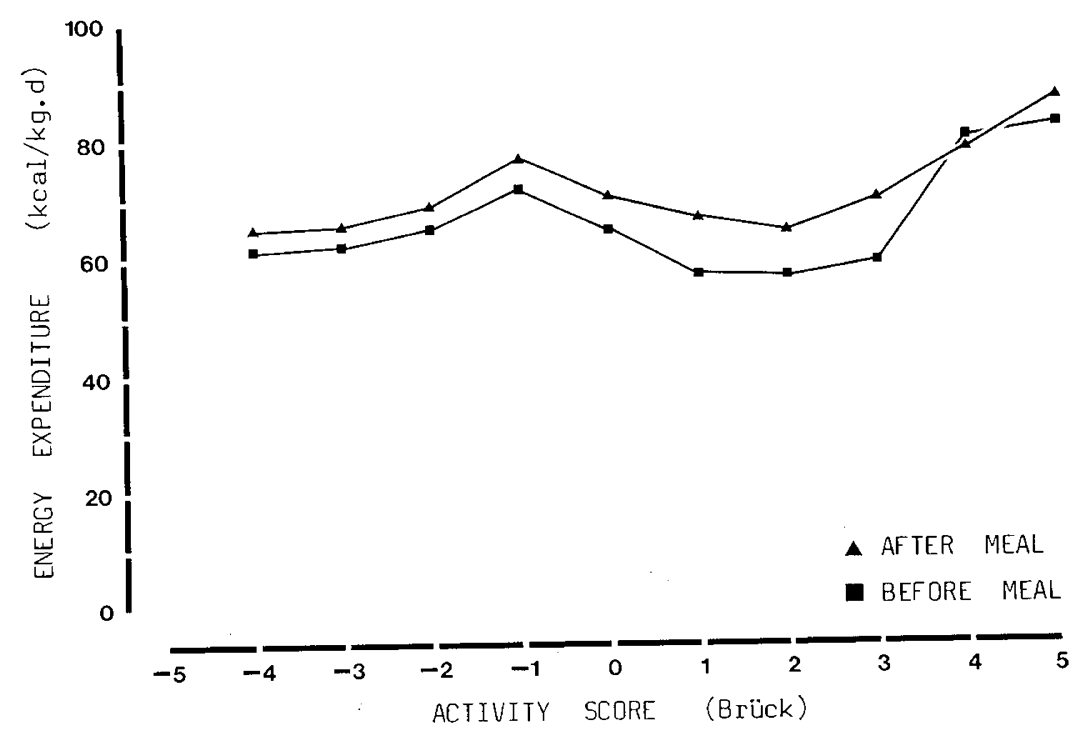

Fig. 2. Relationship between energy expenditure and Brück's (10) activity scale: The premeal values were obtained during the 30-min period before the test meal. The values measured 30-60 min after the meal $\mathbf{\Delta}$ corresponds tothe meal's peak thermogenic effect. There is a lack of linearity between energy expenditure and activity when activity is scored primarily on inspection of the eyes.
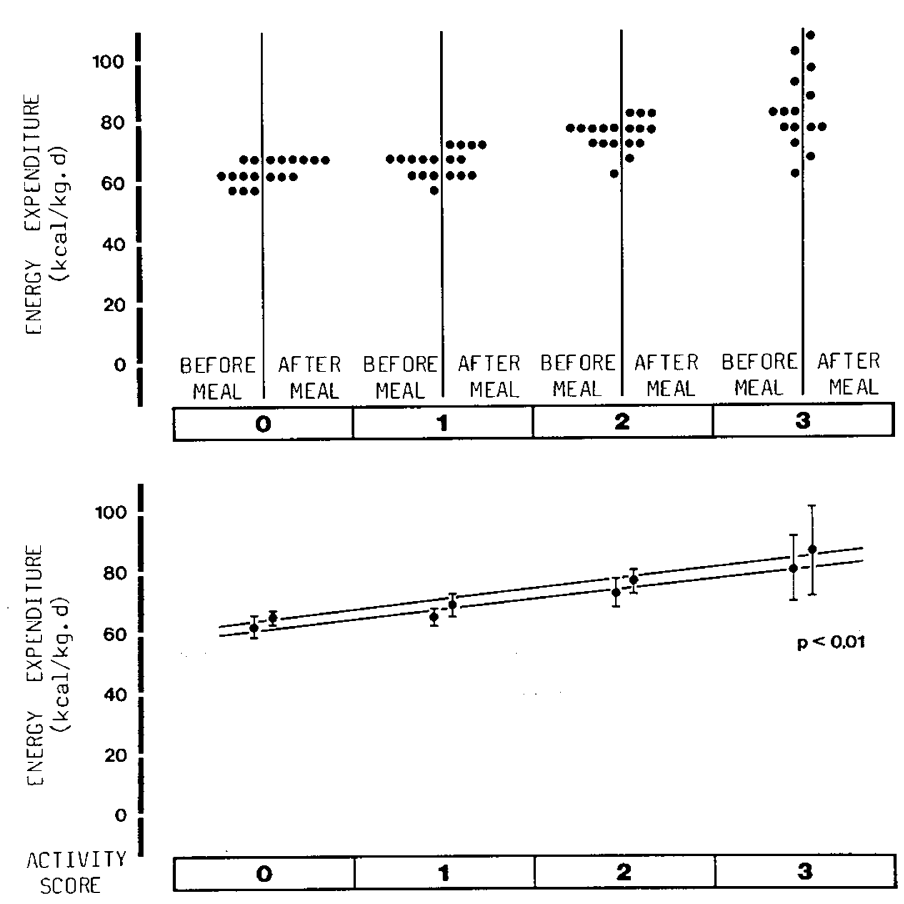

Fig. 3. Relationship between energy expenditure and activity (simplified activity sacle). Upper diagram, each point represent the mean values of energy expenditure at activity score $0-3$. The measurements were done 30-0 $\mathrm{min}$ before and 30-60 min after the meal. Three infants of nine did not cry (score 3) after the meal. Lower diagram, linear relationship obtained between energy expenditure and activity derived from the values of Figure 3 upper diagram. The lower line shows the premeal regression $(\mathrm{y}=60.6+6.67 \times ; r=0.752 ; p<0.001)$, the upper line the postmeal regression $(\mathrm{y}=61.1+6.87 \times ; r=0.739 ; p<0.001)$. At each level of activity there was a significant pre- to postmeal difference in energy expenditure. The mean premeal activity is higher than after the meal $(0.93 \pm 0.19$ versus $0.66 \pm 0.13 ; p<0.05)$.

on the activity scale, $p<0.05$ ). However, at each level of activity, the premeal to postmeal differences in energy expenditure were comparable.

Thermogenic response to feeding (Table 5). If one considers
Table 5. Thermogenic effect of test meals estimated by the "classic" and by the "regression" method (mean $\pm S D)$

\begin{tabular}{lrr} 
& \multicolumn{2}{c}{$13.1 \pm 2.1$} \\
\cline { 2 - 3 } Test meals ME* $(\mathrm{kcal} / \mathrm{kg} / 3 \mathrm{~h})$ & "Classic" & "Regression" \\
\hline Premeal EE $(\mathrm{kcal} / \mathrm{kg} / \mathrm{day})$ & $58.2 \pm 6.0$ & $61.6 \pm 3.4$ \\
Postmeal EE $(\mathrm{kcal} / \mathrm{kg} / \mathrm{day})$ & $69.1 \pm 5.0$ & $64.8 \pm 3.5$ \\
Difference in EE $(\mathrm{kcal} / \mathrm{kg} / 3 \mathrm{~h})$ & $1.3 \pm 0.6$ & $0.4 \pm 0.3$ \\
& & \\
& & \\
Thermogenic response to test meal & & \\
$\%$ of ME in test meal & $9.5 \pm 3.8$ & $3.1 \pm 1.8$ \\
$\%$ of premeal baseline EE & $19.2 \pm 8.4$ & $5.9 \pm 3.2$ \\
\hline * Metabolizable energy. & & \\
$\dagger$ Energy expenditure. & &
\end{tabular}

only the mean energy expenditure, there was no significant premeal to postmeal difference, even during the peak thermogenic period $(66.6 \pm 6.2$ versus $69.3 \pm 3.0 \mathrm{kcal} / \mathrm{kg} /$ day $)$. But, as mentioned previously, the corresponding levels of physical activity were not the same. According to the "classic" estimate, the increase above the premeal baseline energy expenditure was 19.2 \pm 8.4 or $9.5 \pm 3.8 \%$ of the meal's metabolizable energy. However this method compares a zero activity premeal energy expenditure to a postmeal energy expenditure measured at activity levels different from zero $(0.83 \pm 0.17)$. The "regression" method, which compares premeal to postmeal energy expenditure at zero activity levels, gives lower values $-5.9 \pm 3.2 \%$ increase in energy expenditure above baseline and $3.1 \pm 1.8 \%$ of the meal's metabolizable energy.

\section{DISCUSSION}

Nutrient balance and composition of weight gain. The average values for apparent energy, protein (expressed as N), lipid, and carbohydrate digestibility were very close to our previous study (21). They compare with the higher range of reported values $(20$, 23-28). The composition of weight gain in premature babies is the object of daily clinical concerns in the neonatal units. A number of practical considerations preclude the utilization of methods like body density or K-40 measurements to get this information. Therefore bedside, noninvasive methods have to be used and a limited number of investigations have been performed 
$(6,21,23,29,30)$. The measured protein gain as well as the rate of weight gain are comparable to the studies using different milk formulas and different levels of energy intakes $(6,23,29,30)$. By contrast there are differences in fat gain between this and the above mentioned studies which seem closely linked to the difference in metabolizable energy. The comparatively lower metabolizable energy intake in our study resulted in a reduced fat gain despite a similar protein gain.

The composition of weight gain estimated by the two methods (energy and $\mathrm{N}$ balance versus R.Q. method) were similar. The smaller fat retention found with the balance method represents only $5 \%$ of the body weight gain. This is probably the precision within which fat retention can be estimated in premature babies. The comparison between the studied premature babies and fetuses of the same age is interesting, even if there is little rationale to do so. Their growth, in terms of weight gain and protein gain is comparable, whereas their fat gain differs $(23,29,30)$. The premature infants' fat accumulation is higher than intrauterine values at the comparable postconceptional age and lower than that of term babies at a comparable postnatal age. Presently there is a lack of information about "physiologic" ranges of fat gain in premature infants.

Energy cost of activity. A number of authors have developed activity scales based primarily on visual observation of the infant's body movements $(7,9-16)$. Their aim were either to investigate the rate of physical activity as an index of the infant's brain function $(13,14,16)$, or to assess criteria for physical rest in metabolic studies $(7,9,11,12,15,16,31-36)$. In a few studies $(7,9,31-34)$ an attempt was made to determine the energy expenditure at given levels of activity, but no attempt was made to correlate the grade of activity to the rate of energy expenditure. The results obtained by the Brück's scale (10) suggest that, as far as energy expenditure is concerned, some activity levels are not different from each other $(-3,0,+1,+2$ versus -4$)$. These states correspond to very low levels, i.e. no body movements, facial movements present or not, with eyes open or not. The scoring of activity levels, based primarily on the discrimination between open and closed eyes cannot be used to predict energy expenditure. This can be explained for the following reasons: 1) REM-sleep can occur on Brück's scale levels ranging from -4 to +3 . 2) The clinical diagnosis of REMsleep is unreliable in $19 \%$ of the cases (16) and finally, 3) $\dot{\mathrm{VO}}_{2}$ differences between REM and non-REM sleep are controversial $(7,33,34)$.

The simplified activity scale developed in the present study shows a highly significant linear correlation between its four activity levels and their corresponding energy expenditure values (Fig. 3); the slope of the regression line $(6.7 \mathrm{kcal} / \mathrm{kg} / \mathrm{day} / \mathrm{unit})$ represents the energy expended for one unit change in physical activity. Furthermore, the slopes of the regression lines obtained in the premeal and postmeal periods were similar, indicating no difference in the net cost of physical activity between both conditions. The overall energy cost of activity visualized in Figure 4 is close to the reported value of $3-5 \mathrm{kcal} / \mathrm{kg} /$ day (37); the higher values reported by Brooke et al. (9) (23 kcal/kg/day) were obtained at higher activity levels.

Thermogenic response to feeding. There is a conceptual problem that stems from the fact that the thermogenic response to a meal has been investigated in adult human physiology where premeal values were considered to reflect a fasting state. In premature infants this is never the case and the "real" thermogenic effect cannot be measured. Our results, obtained by the "classical" method (see Table 5), are comparable to the published values, $1.1 \mathrm{kcal} / \mathrm{kd} / 4 \mathrm{~h} \mathrm{(9)}$ and $1.7 \mathrm{kcak} / \mathrm{kg} / 4 \mathrm{~h}$ (17). The latter range from 4 to $9 \%$ when expressed as percent of the test meal's metabolizable energy and from 17 to $26 \%$ when expressed as percent increase over the premeal baseline.

With present day's nursing routines eight to 12 meals/day) the premeal baseline cannot be regarded as a basal postabsorbtive value. Prematures are constantly under food stimulation and

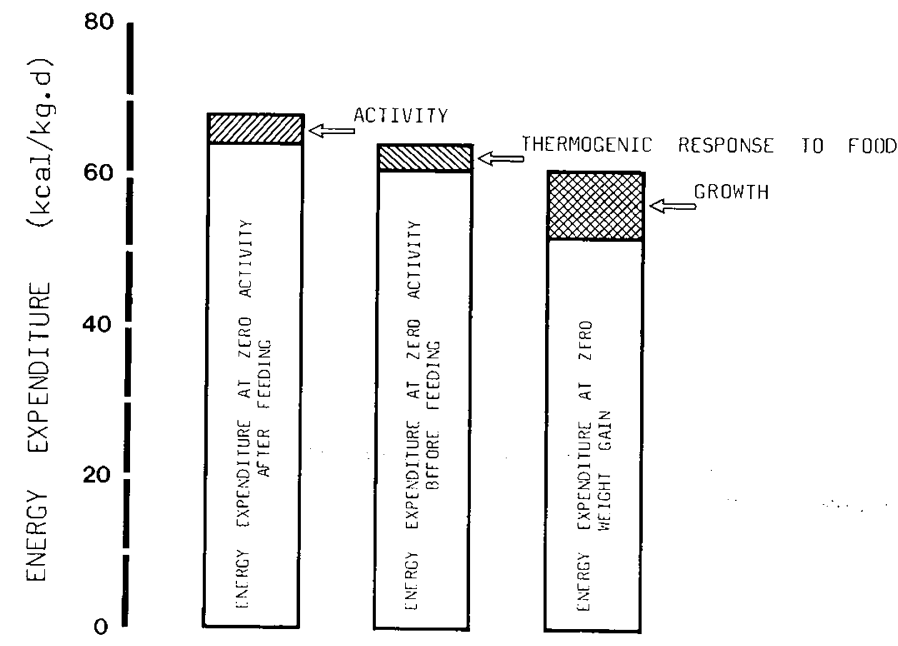

Fig. 4. Partition of energy expenditure between activity and thermogenic response to food. The left column represents the average energy expenditure over $24 \mathrm{~h}(68.4 \pm 4.4 \mathrm{kcal} / \mathrm{kg} /$ day $)$. Using the "regression" method it is possible to assess the postmeal resting energy expenditure $(64.8 \pm 3.5 \mathrm{kcal} / \mathrm{kg} /$ day $)$. The difference between these two values represents the energetic cost of activity. The second column allows the comparison between pre- $(61.6 \pm 3.4 \mathrm{kcal} / \mathrm{kg} / \mathrm{day})$ and postmeal energy expenditure at the zero activity level: the difference in energy expenditure represents the thermogenic effect of food; the third column represents our previous results (5) done with the same method on a comparable sample of premature babies. It shows that the energy expenditure related to physical activity and thermogenic effect of feeding is relatively small compared to the metabolic cost of growth

part of their thermogenic responses are still present in the following premeal energy expenditure. Therefore, the greater the number of meals per day, the smaller the expected postprandial response. Indeed our values obtained with eight meals/day are lower than those reported for a six meals/day study (17). The baseline energy expenditure of the "classic" method must be measured during a motionless premeal period. Since the infants do not stay quiet over the 180 -min postmeal period, the effect of physical activity on energy expenditure is superimposed on the thermogenic effect of the meal. This results in an overestimation of the latter. We attempted to circumvent the difficulty by using the "regression" method to obtain the thermogenic effect of the meals in our nursing conditions. As expected, the obtained thermogenic response was smaller. Finally the results show that the variations of energy expenditure during the course of $24 \mathrm{~h}$ are equally due to physical activity and to the thermogenic effect of feeding (Fig. 4).

Acknowledgments. The authors thank Professor A. Calame, head of the Neonatal Unit, for his support during the study, the nursing staff for their skill and for their help, Judith Hohlfeld, M.D. for editorial assistance, Alfio Marazzi for the statistical work, and the Nestec Research Laboratory for the bomb calorimetries.

\section{REFERENCES}

1. Hill JR, Robinson DC 1968 Oxygen consumption in normally grown, smallfor-dates and large-for-dates newborn infants. J Physiol 199:685-705

2. Lister G, Hoffman JIE, Rudolph AM 1974 Oxygen uptake in infants and children: a simple method for measurement. Pediatrics 53:656-662

3. Smales ORC 1978 Simple method for measuring oxygen consumption in babies. Arch Dis Child 53:53-57

4. Thompson J, Brice JEH, Kurdy NMG, Walker CHM 1979 A modified opencircuit method for estimation of oxygen consumption and carbon dioxide excretion in adults, infants and small animals. Pflügers Arch 380:197-202

5. Gudinchet F, Schutz Y, Micheli JL, Stettler E, Jéquier E 1982 Metabolic cost of growth in very low-birthweight infants. Pediatr Res 16:1025-1030 
6. Abdulrazzaq YM, Brooke OG 1984 Respiratory metabolism in preterm infants: the measurement of oxygen consumption during prolonged periods. Pediatr Res 18:928-931

7. Stabell U, Junge M, Fenner A 1977 Metabolic Rate and $\mathrm{O}_{2}$ consumption in newborns during different states of vigilance. Biol Neonat 31:27-31

8. Rutter N, Brown SM, Hull D 1978 Variations in the resting oxygen consumption of small babies. Arch Dis Child 53:850-854

9. Brooke OG, Alvear J, Arnold M 1979 Energy retention, energy expenditure and growth in healthy immature infants. Pediatr Res 13:215-220

10. Brück K, Parmelee AH, Brück M 1962 Neutral temperature range and range of "thermal comfort" in premature infants. Biol Neonate 4:32-5

11. Oliver TK Jr, Karlberg P 1963 Gaseous metabolism in newly born human infants. The effects of environmental temperature and $15 \%$ oxygen in the inspired air. Am J Dis Child 105:427-435

12. Meystyan J, Jarai I, Fekete M 1968 The total energy expenditure and its components in premature infants maintained under different nursing and environmental conditions. Pediatr Res 2:161-171

13. Prechtl HFR 1974 The behavioral states of the newborn infant (a review) Brain Res 76:185-212

14. Prechtl HFR, Fargel JW, Weinmann HM and Bakker HH 1979 Postures, mobility and respiration of low-risk preterm infants. Dev Med Child Neurol 21:3-27

15. Harpin VA, Chellappah G, Rutter N 1983 Responses of the newborn infant to overheating. Biol Neonate 44:65-75

16. Stefanski M, Shultze K, Bateman D, Kairam R, Pedley TA, Masterson J James LS 1984 A scoring system for states of sleep and wakefulness in term and preterm infants. Pediatr Res 18:58-62

17. Mestyan J, Jarai I, Fekete M, Soltesz G 1969 Specific dynamic action in premature infants kept at and below the neutral temperature. Pediatr Res 3:41-50

18. Alvear J, Brooke OG 1978 Specific dynamic action in infants of low birthweight. J Physiol 275:54P

19. Stothers JK, Warner RM 1979 Effect of feeding on neonatal oxygen consumption. Arch Dis Child 54:415-420

20. Brooke OG 1980 Energy balance and metabolic rate in preterm infants fed standard and high-energy formulas. Br J Nutr 44:13-23

21. Catzeflis C, Schutz Y, Micheli JL, Welsch C, Arnaud MJ, Jéquier E 1985 Whole body protein synthesis and energy expenditure in very low birthweight infants. Pediatr Res 19:679-687

22. Schutz Y, Bessard T, Jéquier E 1984 Diet induced thermogenesis measured over a whole day in obese and nonobese women. Am J Clin Nutr 40:542552

23. Whyte RK, Haslam R, Vlainic C, Shannon S, Samulski K, Campbell D, Bayley HS, Sinclair JC 1983 Energy balance and nitrogen balance in growing lowbirthweight infants fed human milk or formula. Pediatr Res 17:891-898

24. Atkinson SA, Bryan MH, Anderson GH 1981 Human milk feeding in premature infants; protein, fat and carbohydrate balances in the first two weeks of life. J Pediatr 99:617-624

25. Morgan JB, Grimble RF, Whitaker S, Rolles C 1981 Nitrogen and energy balance studies on preterm infants. Proc Nutr Soc 40:109A

26. Chessex P, Reichmann B, Verellen G, Putet G, Smith JM, Heim T, Swyer PR 1984 Metabolic consequences of intrauterine growth retardation in very low birthweight infants. Pediatr Res 18:709-713

27. Voyer M, Senterre J, Rigo J, Charlas J, Satge P 1984 Human milk lactoengineering. Acta Pediatr Scand 73:302-306

28. Roy CC Ste-Marie M, Chartrand L, Weber A, Bard H, Doray B 1975 Correction of the malabsorption of the preterm infant with a medium-chain triglyceride formula. J Pediatr 86:446-450

29. Reichmann B, Chessey P, Putet G, Verellen G, Smith JM, Heim T, Swyer PR 1981 Diet, fat accretion, and growth in preterm infants. N Engl $J$ Med 305:1495-1500

30. Putet $G$, Senterre J, Rigo J, Salle B 1984 Nutrient balance, energy utilization, and composition of weight gain in very-low-birth weight infants fed pooled human milk or a preterm formula. J Pediatr 105:79-85

31. Stothers JK, Warner RM 1977 Thermal balance and sleep state in the newborn infant in a cool environment. J Physiol 273:57P-58P

32. Stothers JK, Warner RM 1977 Oxygen consumption and sleep state in the new-born. J Physiol 269:57P-58P

33. Stothers JK, Warner RM 1977 Oxygen consumption and the new-born infan in a cool environment, measured with regard to sleep state. J Physio 272:16P-17P

34. Stothers JK, Warner RM 1978 Oxygen consumption and neonatal sleep states. J Physiol 278:435-440

35. Mestyan J, Fekete M, Bata G, Jarai I 1964 The basal metabolic rate of premature infants. Biol Neonate 7:11-25

36. Reichman RL, Chessex P, Putet G, Verellen GJE, Smith JM, Heim T, Swyer PR 1982 Partition of energy metabolism and energy cost of growth in the very low-birth-weight infant. Pediatrics 69:446-451

37. Mestyan J 1978 Energy metabolism and substrate utilization in the new-born In: Sinclair JC (ed) Temperature Regulation and Energy Metabolism in the New-Born. pp 39-74

\section{APPENDIX}

Gross energy and nutrient intakes apparent digestibility and metabolizable energy.
Energy equivalent of $\mathrm{CHO}$ intake $(\mathrm{E} \mathrm{CHO})$ in $\mathrm{kcal} / \mathrm{g}$ :

$\mathrm{E} \mathrm{CHO}=\mathrm{GE}-(\mathrm{g} \mathrm{N} \times 6.38 \times 5.6)-(\mathrm{g}$ lipid $\times 9.25) \quad$ Eq 1

$\mathrm{GE} \quad$ gross energy of milk (kcal/ $\mathrm{kg} /$ day)

$6.38 \mathrm{~g}$ of milk protein per g Nitrogen

5.6 gross energy equivalent of protein $(\mathrm{kcal} / \mathrm{kg} / \mathrm{day})$

9.25 gross energy equivalent of lipid $(\mathrm{kcal} / \mathrm{kg} / \mathrm{day})$

$\mathrm{CHO}$ intake (I CHO) in $\mathrm{g} / \mathrm{kg} /$ day:

$\mathrm{I} \mathrm{CHO}=\mathrm{E} \mathrm{CHO} / 3.95$

3.95 gross energy equivalent of lactose $(\mathrm{kcal} / \mathrm{kg} / \mathrm{day})$

Apparent digestible energy (DE) in $\mathrm{kcal} / \mathrm{kg} /$ day:

$\mathrm{DE}=\mathrm{GE}-\mathrm{E}$ feces

$\mathrm{DE}(\%)=(\mathrm{GE}-\mathrm{E}$ feces $) \times 100 / \mathrm{GE}$

Eq 3

Apparent $\mathrm{N}$ digestibility $(\mathrm{DN})$ in $\mathrm{mg} / \mathrm{kg} /$ day:

$\mathrm{DN}=\mathrm{N}$ intake $-\mathrm{N}$ feces

$\mathrm{DN}(\%)=\frac{(\mathrm{N} \text { intake }-\mathrm{N} \text { feces }) \times 100}{\mathrm{~N} \text { intake }}$

Eq 4

Apparent lipid digestibility (DL) in $\mathrm{g} / \mathrm{kg} /$ day

$\mathrm{DL}=$ lip. intake-fecal lip.

$\operatorname{DL}(\%)=\frac{\text { (lip. intake }- \text { fecal lip.) } \times 100}{\text { lipid intake }}$

Eq 5

Apparent $\mathrm{CHO}$ digestibility $(\mathrm{D} \mathrm{CHO})$ in $\mathrm{g} / \mathrm{kg} /$ day:

$\mathrm{D} \mathrm{CHO}=\mathrm{CHO}$ intake $-\mathrm{CHO}$ feces

$\mathrm{D} \mathrm{CHO}(\%)=\frac{\mathrm{CHO} \text { intake }-\mathrm{CHO} \text { feces } \times 100}{\mathrm{CHO} \text { intake }}$

Eq 6

$\mathrm{CHO}$ feces $=[\mathrm{E}$ feces $-($ fecal lipid $\mathrm{E}+$ fecal protein $\mathrm{E})] /$ 3.75

$\mathrm{Eq} 7$

The gross energy equivalent of fecal protein, lipid and $\mathrm{CHO}$

are respectively $5.6,9.3$ and $3.75 \mathrm{kcal} / \mathrm{g}$

$\mathrm{CHO}$ in feces are assumed to be monosaccharide

Metabolizable energy intake (ME) in $\mathrm{kcal} / \mathrm{kg} /$ day:

$\mathrm{ME}=\mathrm{GE}-(\mathrm{E}$ feces $-\mathrm{E}$ urine $)=\mathrm{DE}-\mathrm{E}$ urine $\quad \mathrm{Eq} 8$

Energy expenditure (EE) measured by indirect calorimetry in $\mathrm{kcal} / \mathrm{kg} / \mathrm{day}$.

$\mathrm{EE}=4.686+\frac{(\mathrm{NPRQ}-0.707) \times 0.361 \mathrm{NPV}_{2}+4.46 \mathrm{PVO}_{2}}{0.293}$

Eq 9

$\mathrm{PVO}_{2}$ oxygen consumed by protein oxidation in $1 / \mathrm{kg} /$ day

$\mathrm{NPV}_{2}$ nonprotein oxygen consumption in $1 / \mathrm{kg} /$ day

NPRQ nonprotein respiratory quotient

0.707 NPRQ for total fat oxidation

0.293 difference in NPRQ between that of fat oxidation and CHO oxidation $(1-0.707)$

4.686 caloric equivalent $\left(\mathrm{kcal} /\right.$ liter $\left.\mathrm{O}_{2}\right)$ of 1 liter oxygen at $\mathrm{NPRQ}=0.707$

0.361 difference between the caloric equivalents of one liter oxygen at a NPRQ of 1 and 0.707

4.64 caloric equivalent $(\mathrm{kcal} / \mathrm{kg} /$ day $)$ of one liter oxygen when protein is oxidized

Oxidation rates in protein, lipid and $C H O(P$ ox, $L$ ox, CHO ox) in $\mathrm{g} / \mathrm{kg} /$ day.

$\mathrm{P}$ ox $=\mathrm{N} \times 6.25 \times 0.966$

$\mathrm{Eq} 10$

$\mathrm{L}$ ox $=\mathrm{NPV்O}_{2} \times \frac{(1-\mathrm{NPRQ})}{0.293 \times 2.019}$

Eq 11

$\mathrm{CHO}$ ox $=\mathrm{NPVO}_{2} \times \frac{(\mathrm{NPRQ}-0707)}{0.293 \times 0.829}$

Eq 12

$\mathrm{N}$ total Nitrogen excretion in $\mathrm{g} / \mathrm{kg} /$ day

6.25 protein equivalent of $\mathrm{N}$

0.966 volume of oxygen required to oxidize one $\mathrm{g}$ of protein

2.019 volume of oxygen required to oxidize one $\mathrm{g}$ of lipid

0.829 volume of oxygen required to oxidize one $\mathrm{g}$ of $\mathrm{CHO}$ expressed as starch

Energy gain in $\mathrm{kcal} / \mathrm{kg} /$ day, protein gain, $\mathrm{CHO}$ gain, and lipid gain in $\mathrm{g} / \mathrm{kg} / \mathrm{day}$.

a. Energy and $\mathrm{N}$ balance method:

$\mathrm{E}$ gain $=\mathrm{ME}-\mathrm{EE}$

$\mathrm{N}$ gain $=$ gross $\mathrm{N}$ intake $-($ fecal + urinary $\mathrm{N})$

$\mathrm{Eq} 13$

$\mathrm{P}$ gain $=\mathrm{N}$ gain $\times 6.25$

Eq 14

$\mathrm{CHO}$ gain is assumed to be negligible
Eq 15 
$\mathrm{L}$ gain $=\mathrm{E}$ stored in lipid $/ 9.25=\mathrm{E}$ gain $-(\mathrm{P}$ gain $\times 5.6) /$ 9.25

b. R.Q. method:

Eq 16

$\mathrm{N}$ gain $=$ gross $\mathrm{N}$ intake $-($ fecal + urinary $\mathrm{N})$

$\mathrm{P}$ gain $=\mathrm{N}$ gain $\times 6.25$

$\mathrm{CHO}$ gain $=\mathrm{MCHO}-\mathrm{CHO}$ ox

$\mathrm{L}$ gain $=\mathrm{ML}-\mathrm{L}$ ox

$\mathrm{ME}$ metabolizable energy intake $(\mathrm{kcal} / \mathrm{kg} /$ day $)$

ML metabolizable lipid intake $(\mathrm{g} / \mathrm{kg} /$ day $)$

MCHO metabolizable CHO intake $(\mathrm{g} / \mathrm{kg} /$ day $)$

Fat free mass gain (FFM) in $\mathrm{g} / \mathrm{kg} /$ day:

FFM gain = weight gain - lipid gain methods.

a. The "classic" method:

TEF (\%) over premeal baseline EE

$=\underline{(\text { postmeal EE }- \text { premeal baseline EE }) \times 100}$ premeal baseline EE

Eq 20

TEF (\%) of testmeal ME

$$
=\frac{(\text { postmeal EE }- \text { premeal baseline EE }) \times 100}{\text { ME content of test }}
$$

$$
\text { ME content of test meal }
$$

Eq 17

Eq 18

Eq 19

premeal baseline EE is the EE measured over a 3- to 5-min period of inactivity ( 0 activity on the simplified scale) during the 30 -min premeal period

postmeal EE is the EE measured over 180 min after the testmeal.

b. The "regression" method:

TEF (\%) over premeal EE $=\frac{(\text { postmeal EE }- \text { premeal EE }) \times 100}{\text { premeal EE }}$

Eq 22

TEF (\%) of testmeal ME $=\frac{(\text { postmeal EE }- \text { premeal EE }) \times 100}{\mathrm{ME}}$

ME content of test meal

premeal $\mathrm{EE}$ is the value of the premeal regression line (EE versus $0-3$ activity score) at the zero activity intercept.

the premeal regression line is obtained by plotting the minute by minute EE measurements versus activity during the 30 min premeal period.

postmeal $\mathrm{EE}$ is the value of the postmeal regression line (EE versus $0-3$ activity score) at the zero activity intercept.

the postmeal regression line is obtained by plotting the minute by minute EE measurements versus activity during the 180-min postmeal period. 